Ann. Biol. anim. Bioch. Biophys., 1979, 19 (3 A), 647-659.

\title{
Plasma calcitonin and parathyroid hormone levels in growing pigs on different diets. II. Low calcium diet.
}

\author{
par A. POINTILLART, J. M. GAREL *, L. GUÉGUEN \\ with the technical assistance of Colette COLIN \\ Station de Recherches de Nutrition, I.N.R.A., \\ 78350 Jouy-en-josas, France \\ * Physiologie du Développement, Université P. ef M. Curie, \\ 9, quai St-Bernard, 75230 Paris-Cedex 05, France.
}

Summary. Four 12 -week old growing pigs were fed a control diet $(0.5$ p. 100 calcium) and then a low calcium diet containing 0.1 p. 100 calcium. Two hours after the morning meal and 5 hours later in the afternoon, plasma concentrations of calcium, magnesium, inorganic phosphorus, calcitonin and parathyroid hormone (PTH) were studied during the control period and during the 6 weeks of low calcium diet.

Samples were collected in four 10-day periods, one during the control diet and 3 after introducing the low calcium diet (low $\mathrm{Ca} \mathrm{1}$, low $\mathrm{Ca} 2$ and low $\mathrm{Ca} \mathrm{3)}$; only 7 days of each period were used for statistical analysis.

Plasma calcium and calcitonin (CT) levels were significantly decreased and urinary hydroxyproline was increased during the low Ca diet.

The appearance of tetany crisis (just before low $\mathrm{Ca}$ 2) was concomittant with a slight but significant decrease in plasma PTH levels.

Plasma magnesium level was more elevated during the periods 2 and 3 of low $\mathrm{Ca}$ than during low $\mathrm{Ca} 1$ or control periods. No rise in plasma PTH level occurred during the low calcium diet; this fact has been discussed in relation to dietary vitamin D or magnesium content.

The absence of change in plasma PTH levels in response to the slight decrease in calcemia (12 p. 100 maximum) suggested that pigs are able to adapt to unbalanced calciumphosphorus diets. However, bone disturbances (nasal septum and mandible) were observed as well as increased levels of urinary hydroxyproline, which indicate that the use of plasma calcium and PTH levels were not sufficient for determining the severity of dietary calcium deficiency.

Our data seemed to confirm that CT in this species might play a more important role than PTH in plasma calcium regulation. Special attention has been given to the role of plasma magnesium in CT-PTH relationships.

\section{Introduction.}

In lactating cows the marked hypocalcemia occurring during parturient paresis is associated with elevated values of plasma parathyroid hormone (PTH) (Blum, Mayer and Potts, 1974 ; Blum et al., 1974 ; Garel and Barlet, 1975). A rise in plasma PTH levels is also observed after intravenous infusion of EGTA or EDTA in cows (Blum and Fischer, 1975 ; Sherwood et al., 1966 ; Saeki and Hayashi, 1976). However, 
when dietary calcium intake is increased from 0.05 to $1.4 p$. 100, neither calcemia nor plasma PTH level is changed in cows (Ramberg ef al., 1976.)

Histological findings in pigs have suggested that a low $\mathrm{Ca}: \mathrm{P}$ ratio $(0.5)$ induces an increase in parathyroid activity as compared with that observed using a normal $\mathrm{Ca}: \mathrm{P}$ ratio (1.2) (Nuñez, Krook and Whalen, 1976); this agrees with a previous observation of Doige, Owen and Mills (1975). In contrast, we found no rise in plasma PTH level with a Ca-P ratio of 0.5 (Pointillart, Garel and Guéguen, 1978b) ; however, we used a dietary calcium and phosphorus intake ( 0.6 p. $100 \mathrm{Ca}$ and 1.2 p. $100 \mathrm{P}$ ) different from that given by Nuñez et al. (1976) (0.8 p. $100 \mathrm{Ca}$ and $1.6 \mathrm{p} .100 \mathrm{P})$ and Doige ef al. (1975) (0.33 p. $100 \mathrm{Ca}$ and 0.75 p. $100 \mathrm{P}$ ). According to some data, increased bone resorption was reported to result from a low dietary calcium intake (Doige ef al., 1975 ; Horvath and Papp, 1972 ; Stockland and Blaylock, 1973), but other authors have shown that bone composition was unchanged in such conditions (Pond, Walker and Kirtland, 1978). The latter finding suggested an adaptation of pigs to different intakes of calcium and phosphorus. The aim of the present work was to elucidate the influence of a low dietary calcium intake on plasma PTH and calcitonin (CT) concentrations in growing pigs.

\section{Material and methods.}

Animals, diets and sampling.

Four 12-week old Large-White male pigs weighing $27.8 \pm 0.5 \mathrm{~kg}$ were used. Samples were collected in four 9 to 10-day periods, one during the control diet period and 3 after introducing the new diet. Only 7 days of each period were used for equilibrium of the variance analysis.

A chronically implanted catheter was fitted to collect blood samples twice daily from the jugular vein. The first blood sample was collected $2 \mathrm{hrs}$. after the morning meal and the second one $5 \mathrm{hrs}$. later to see if there was any meal effect or if a lag period was necessary before changes occurred. The afternoon meal was given just after the second blood puncture, i. e. 7 hrs. after the morning meal. Each sample was collected in a heparinized polyethylene tube maintained in an ice-bath. Samples intended for hormone assays were collected under peptidase inhibitors (Iniprol, Laboratoires Choay, Paris, France). After centrifugation at $4^{\circ} \mathrm{C}$, plasma samples were frozen at $-30^{\circ} \mathrm{C}$ until hormone assay.

During the first period the pigs were fed a control diet including 72 p. 100 maize, 26 p. 100 soya meal and 2 p. 100 mineral-vitamin mixture. This diet contained 0.52 p. 100 calcium, 0.67 p. 100 phosphorus and 0.2 p. 100 magnesium. During the next 6 weeks until slaughter, the animals received the same diet but with no calcium source in the mineral mixture, and then $\mathrm{Ca}, \mathrm{P}$ and $\mathrm{Mg}$ contents were $0.12,0.55$ and 0.17 p. 100 , respectively.

Plasma analysis.

Plasma calcium was measured by flame photometry (Eppendorf) and plasma magnesium by atomic absorption spectrophotometry (IL 151). Plasma inorganic phosphorus was estimated by colorimetry (Chen, Toribara and Warner, 1956). 
Plasma CT levels were measured by radioimmunoassay in a system already described in detail (Garel, Care and Barlet, 1974 ; Garel, Savajol and Barlet, 1976). This assay involved the use of purified porcine CT (Lot K 600-072 F-2; 116 MRC units/mg ; Armour Pharmaceutical Co., Kankakee, Illinois, USA) for iodination through the chloramine-T method of Hunter and Greenwood (1962). The ${ }^{125}$-labelled porcine CT was purified by gel filtration on Sephadex G-50 fine. The specific activities of 200$300 \mu \mathrm{Ci} / \mu \mathrm{g}$ were achieved routinely. The same batch of purified porcine CT was also used as a standard. An antiserum $\left(\mathrm{GP}_{4}\right)$, raised in a guinea-pig against porcine CT, was employed at a final dilution of $1: 3000$. The tubes were incubated in an equilibrium system at $4^{\circ} \mathrm{C}$, and after 6 days were phase-separated on talcum powder. The sensitivity of the assay was $0.25 \mathrm{ng} / \mathrm{ml}$ plasma.

The plasma PTH level was also measured by radioimmunoassay using a bovine system already described (Garel and Barlet, 1976) which cross-reacted with porcine PTH. Purified bovine PTH (bPTH 1-84, a gift of J. A. Parsons and J. M. Zanelli, MRC. London, England) was labelled with ${ }^{125}$ using the chloramine-T method (Hunter and Greenwood, 1962) and purified through gel filtration on Sephadex G-50 fine. Standard curves were calibrated with pure bovine PTH (bPTH 1-84, a gift of G. D. Aurbach). An antibody, raised in a goat against partially purified bovine PTH, was employed at a final dilution of $1: 8000$. Since it did not cross-react with the synthetic bovine 1-34 fragment, this antibody was specific against the carboxyl terminal part of the PTH molecule. After incubation for 6 days at $4^{\circ} \mathrm{C}$ in an equilibrium system, the bound and the free labelled fractions were separated by adsorption on plasma-coated charcoal. The results were expressed in $\mathrm{ng}$ equivalents bovine PTH per ml plasma. The sensitivity of the assay was $0.3 \mathrm{ng} / \mathrm{ml}$ plasma. Inter-assay variations were excluded since all plasmas were measured in the same assay. Intra-assay variation was no more than 10 p. 100.

Urinary hydroxyproline. - Urine was collected for 2 days during each period. Hydroxyproline was determined by colorimetry (Borel, Caranjot and Jayle, 1967) after pyrrole distillation (Serafini-Cessi and Cessi, 1964).

Statistical analysis. - Several variance analyses were done with a computer in order to determine the significance of the differences observed by changing the diet, the variations between periods, the differences between morning and afternoon samples, and individual variations and interactions between the different sources of variability (pigs, days, periods, sampling hours). The method was the same as previously mentioned (Pointillart, Garel and Guéguen, 1978b), and also gave a linear correlation. All data on the figures are presented as means \pm the standard error of the means.

\section{Results.}

A small but significant decrease in calcemia (12 p. 100) was induced by the low calcium diet (figs 1 and 3). Plasma CT level was greatly decreased (35.5 p. 100) and plasma PTH level was slightly (9.2 p. 100) reduced (figs. 2, 6 and 7). An increase in magnesium (figs. 1 and 5), was observed as well as a marked elevation in urinary 
hydroxyproline (32 p. 100 in the first 15 days and 73 p. 100 at the end of the experiment) (fig. 2). Phosphatemia was unchanged after introduction of the low calcium diet (fig. 1 and 4).
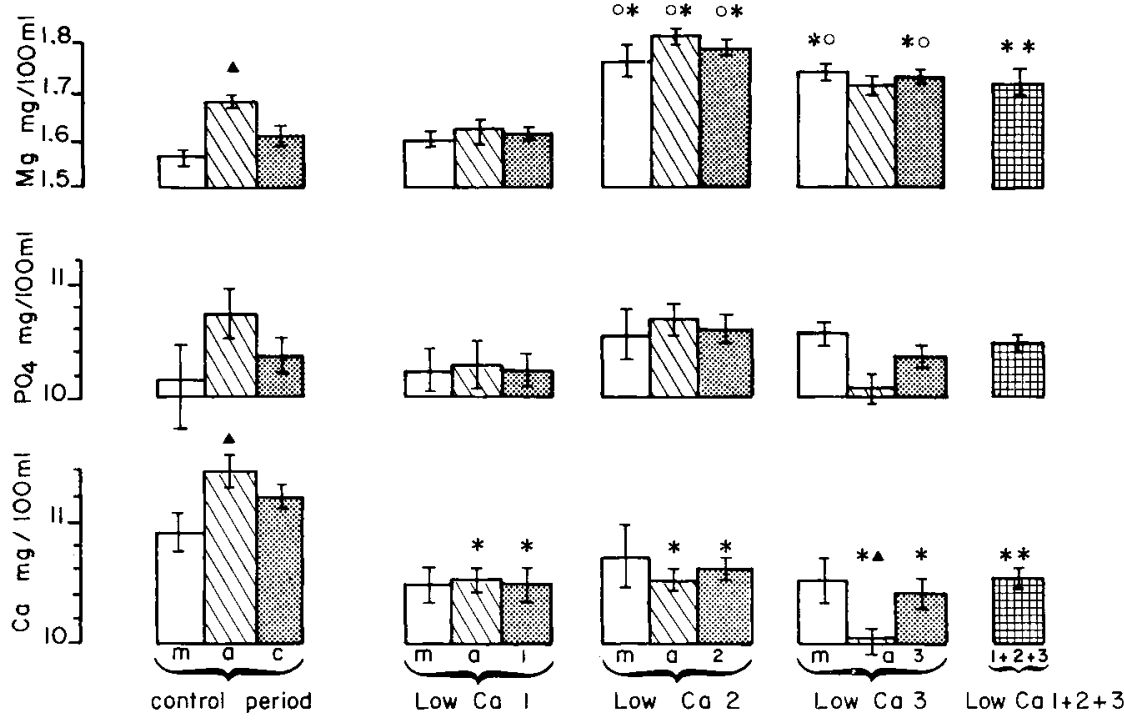

FIG. 1. - Morning ( 2 hrs after the meal), afternoon ( 5 hrs loter) and daily plasmo concentrations of calcium, phosphate, magnesium in growing pigs fed a control and then a low calcium diet. Period means and overall low Ca means.

Legend (fig. 1 et 2) :

$\square$ morning means; $\mathrm{Wafternoon}$ means; daily means; over all low Ca means; $\because \mathrm{P}<0.05(* *)$ compared to control period $(\mathrm{P}<0.01) ;$ o $\mathrm{P}<0.05$ compared to low $\mathrm{Ca} \mathrm{I}$; - $P<0.05$ compared to low Ca $2 ; A<0.05$ compared to morning.

Differences in the parameters studied were observed during the three periods of the low calcium diet (fig. 1 and 2). During the first low-calcium period (the first 15 days), plasma CT level fell from $4.8 \mathrm{ng} / \mathrm{ml}$ (control period) to $3.3 \mathrm{ng} / \mathrm{ml}$. Calcemia decreased $(10.5 \mathrm{mg} / 100 \mathrm{ml}$ vs. $11.2 \mathrm{mg} / 100 \mathrm{ml}$ in the control period), but plasma PTH levels were unchanged; plasma concentrations of magnesium and inorganic phosphorus both did not change. During the second low-calcium interval occurring after a period of tetany crisis, there was a slight decrease in plasma PTH level (2.31 vs. $2.60 \mathrm{ng} / \mathrm{ml}$ in the first period and vs. $2.65 \mathrm{ng} / \mathrm{ml}$ in the control period) and an increase in magnesemia (1.78 vs. $1.61 \mathrm{mg} / 100 \mathrm{ml}$ in the first low $\mathrm{Ca}$ or the control period).

During the third low-calcium period (weeks 5 and 6 of the low calcium intake), the plasma CT levels remained low with values similar to those observed in the first and second low-calcium periods (3.6 vs. $4.8 \mathrm{ng} / \mathrm{ml}$ in the control period). Magnesemia was higher in the third low-calcium period than during the control period (1.73 vs. $1.61 \mathrm{mg} / 100 \mathrm{ml}$ ). The plasma PTH level slightly increased and recovered the 
values of the control period ( $2.57 \mathrm{vs.} 2.65 \mathrm{ng} / \mathrm{ml}$ in the control period). The low plasma calcium values were similar to those found in the first two intervals of low-calcium diet in spite of the long-term effect of the treatment (6 weeks).
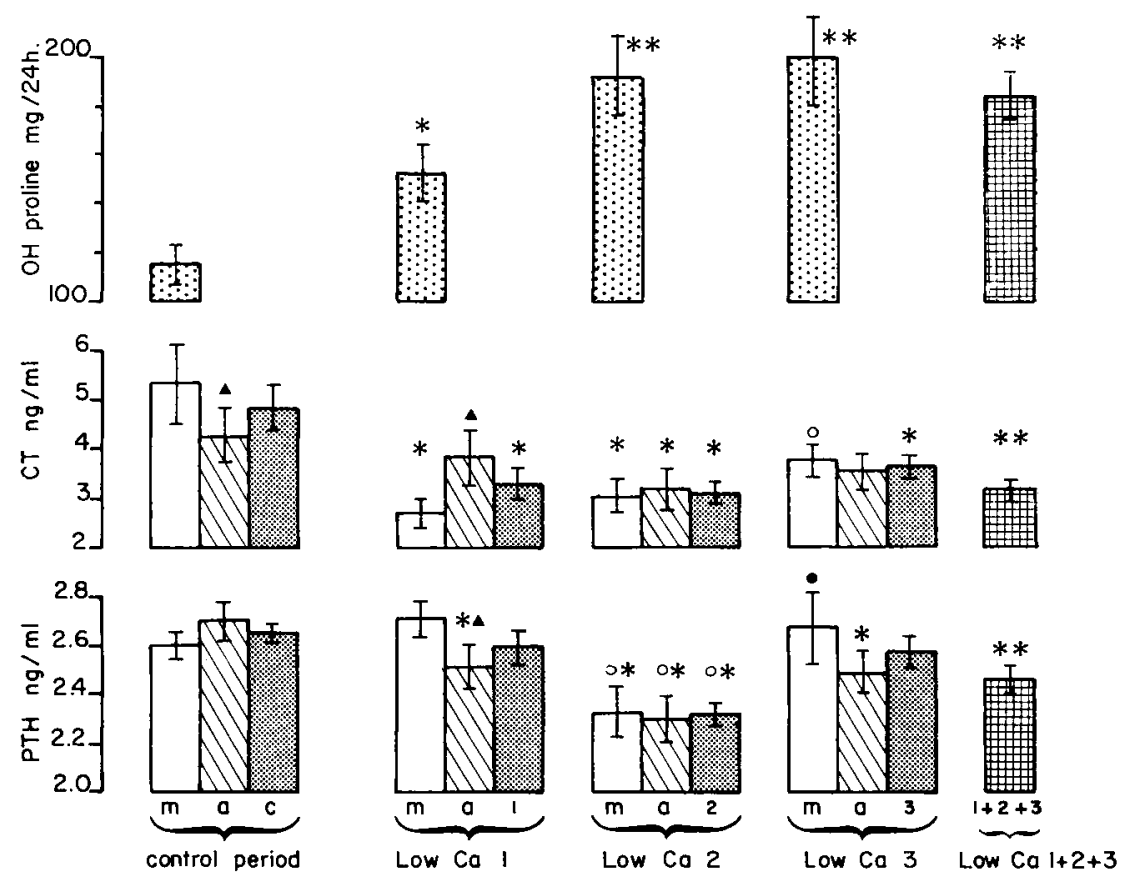

FIG. 2. - Morning, afternoon and daily plasmo concentrations of calcitonin (CT), parathyroid hormone (PTH) and urinary hydroxyproline in growing pigs fed a control and then a low calcium diet. Period means and overall low Ca means.

Legend : see fig. 1. - Urinary hydroxyproline : mean values of 2 days for each period.

However, some differences were only significant for morning or for afternoon values, even if they could be significant for daily means (fig. 1 and 2). For example, morning values for plasma PTH levels increased during the third low calcium period ( $2.67 \mathrm{vs} .2 .32 \mathrm{ng} / \mathrm{ml}$ in the second low calciu m interval), but afternoon values for plasma PTH levels during the third low calcium period were not different from those observed in the second period ( 2.48 vs. $2.30 \mathrm{ng} / \mathrm{ml}$ ).

The main changes introduced by the low calcium diet were a decrease in plasma calcium concentration, a fall in plasma CT level and an increase in urinary hydroxyproline. Plasma PTH levels did not increase and magnesemia was often elevated.

During the control period, plasma CT levels were higher in the morning than in the afternoon (5.3 vs. $4.2 \mathrm{ng} / \mathrm{ml}$ ) (fig. 2). On the contrary, plasma calcium concentrations were higher in the afternoon than in the morning (11.4 vs. $10.5 \mathrm{mg} / 100 \mathrm{ml})$ (fig. 1). During the period of low calcium diet plasma CT level was lower in the morning than in the afternoon $(2.7$ vs. $3.9 \mathrm{ng} / \mathrm{ml})$, and the opposite was observed for plasma PTH levels ( 2.7 vs. $2.5 \mathrm{ng} / \mathrm{ml}$ ) (fig. 2 ). 
During the control period, the plasma magnesium concentration was higher in the afternoon than in the morning $(1.67$ vs. $1.56 \mathrm{mg} / 100 \mathrm{ml}, \mathrm{P}<0.01)$; this difference disappeared when the pigs were fed the low calcium diet (fig. 1). During the last 2 weeks of this diet, calcemia was lower in the afternoon than in the morning (10.03 vs. $10.50 \mathrm{mg} / 100 \mathrm{ml}, \mathrm{P}<0.05$ ) (fig. 2).

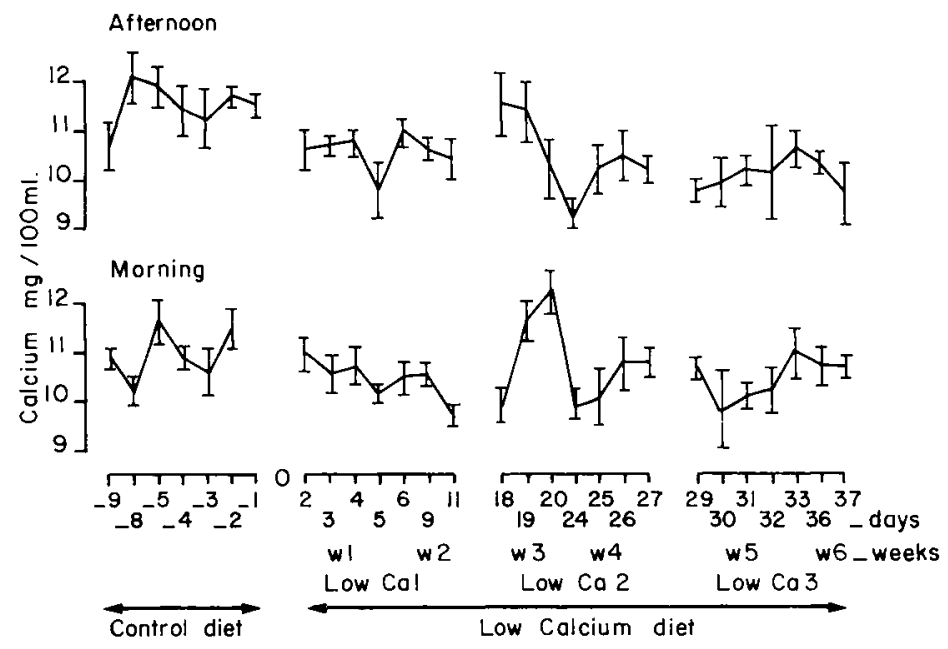

FIG. 3. - Morning and afternoon plasma concentrations of calcium in growing pigs fed a control and then a low calcium diet. Daily means.

Legend. Abcissae : number of days before ( - ) and after the introduction of the low calcium diet (time.

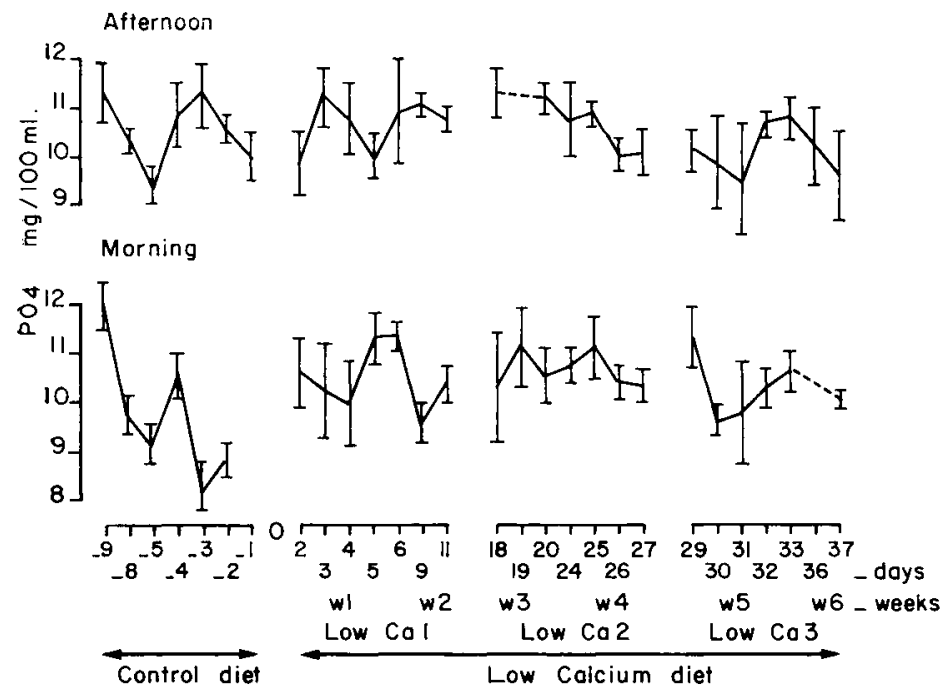

FIG. 4. - Morning and afternoon plasma concentrations of inorganic phosphorus $\left(\mathrm{PO}_{4}\right)$ in growing pigs fed a control and then a low calcium diet. Daily means.

Legend : see fig. 3. 
Strong correlations did not appear whatever the period examined, but significant weak correlations were often observed, which mean that several factors were involved in the variations of one parameter. In the control period, there was a negative correlation between $\mathrm{Mg}$ and $\mathrm{CT}(\mathrm{r}=-0.51, \mathrm{P}<0.01)$ and a positive correlation between $\mathrm{Mg}$ and $\mathrm{PO}_{4}(r=+0.44, \mathrm{P}<0.01)$. During the period of low calcium diet many positive correlations appeared : $\mathrm{Ca} / \mathrm{PO}_{4}(r=+0.35, \mathrm{P}<0.01), \mathrm{Ca} / \mathrm{Mg}(r=+0.25$, $\mathrm{P}<0.05) ; \mathrm{PTH} / \mathrm{Mg}(r=+0.27, \mathrm{P}<0.01)$. Some changes in correlation occurred between periods of observation ; a negative correlation was observed between $C T$ and PTH during the first $(r=-0.30, \mathrm{P}<0.05)$ and third $(r=-0.46, \mathrm{P}<0.01)$ low calcium intervals, but this correlation was not found in the second low calcium period. A positive correlation between PTH and $\mathrm{Mg}$ appeared during the first and second periods ( $r=+0.42$ and $+0.40, P<0.01$, respectively) of the low calcium diet but not in the third period in which a negative correlation was found between $C T$ and $\mathrm{Mg}(\mathrm{r}=-0.36, \mathrm{P}<0.05)$ and between $\mathrm{CT}$ and $\mathrm{Ca}(\mathrm{r}=-0.36, \mathrm{P}<0.05)$.

Pig effect was significant for all parameters studied. There were also significant pig-period interactions, except for calcemia and plasma PTH levels. The hour-period interaction was significant for plasma levels of PTH and CT.



FIG. 5. - Morning and afternoon plasma concentrations of magnesium in growing pigs fed a control and then a low calcium diet. Daily means.

Legend : see fig. 3.

Great variations were observed from one day to another in the same period, particularly during the control period for plasma concentrations of calcium (fig. 3), inorganic phosphorus (fig. 4) and CT (fig. 7). Moreover, no peak was present, but a trend towards elevated plasma calcium values was observed at the end of the third 
week of low calcium diet (fig. 3) after the occurrence of tetany crisis and when the lowest levels of plasma PTH were found (2.05 and $2.20 \mathrm{ng} / \mathrm{ml}$ ) (fig. 6).

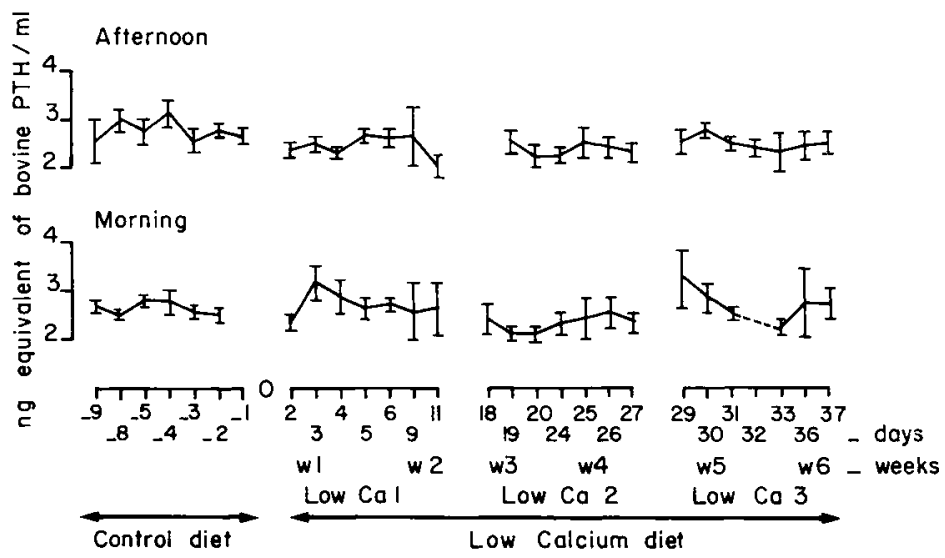

FIG. 6. - Morning and afternoon plasma concentrations of parathyroid hormone (PTH) in growing pigs fed a control and then a low calcium diet. Daily means.

Legend : see fig. 3.

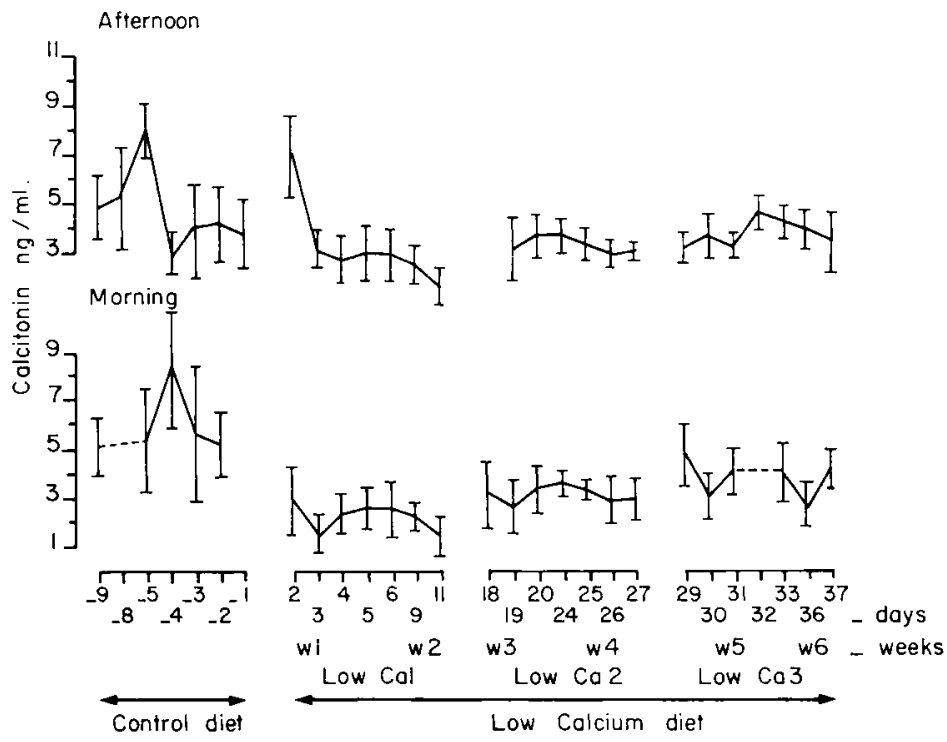

FIG. 7. - Morning and afternoon plasma concentrations of calcitonin in growing pigs fed a control and then a low calcium diet. Daily means.

Legend : see fig. 3.

\section{Discussion.}

Our results demonstrate that a low calcium diet $(0.12$ p. 100) induces a simultaneous decrease in plasma calcium and CT concentrations without change in plasma PTH levels. However, the marked rise in urinary hydroxyproline may suggest an increase in bone resorption. 
Fox ef al. (1977) have shown in pigs that neither PTH nor CT was necessary for intestinal adaptation to a low calcium dief since thyroparathyroidectomized pigs were able to increase their intestinal calcium absorption in response to the low calcium diet. We have observed that intestinal Ca-BP concentration was increased in pigs fed this low calcium diet (Thomasset et al., 1979). The increased bone resorption suggested by the rise in urinary hydroxyproline may result from the fall in plasma CT levels. In hypocalcemic parturient cows, lowered plasma CT levels have been described by Mayer, Blum and Deftos (1975) and were associated with increased plasma PTH levels (Blum, Mayer and Potts, 1974). However, a rise in both plasma CT and PTH levels was reported by Garel and Barlet (1975) in hypocalcemic parturient cows, and Barlet (1971) has attributed parturient hypocalcemia to the stimulation of CT secretion. In the present experiments, hypocalcemia was associated with a fall in plasma CT levels, but plasma PTH levels remained unchanged. Moreover, a negative correlation was observed between $\mathrm{Ca}$ and $\mathrm{CT}$ during the third period of the low calcium dief, whereas no correlation appeared between $\mathrm{Ca}$ and PTH.

The appearance of tetany crisis at a time when plasma PTH levels were low suggested a disturbance in hormonal secretions. Some other factors, such as the high dietary magnesium content, may explain the low level of PTH. Elevated plasma magnesium levels are known to inhibit the secretion of PTH (Massry, Coburn, and Kleeman, 1970 ; Radde,Wittermann and Pensuwan, 1968). Thus, in the second period, when the highest plasma magnesium levels were reached, the plasma PTH levels were very low. We must also emphasize the high dietary intake of vitamin $D$ $(2500 \mathrm{lU} / \mathrm{kg})$ used in these experiments; it is well-known that $1.25(\mathrm{OH})_{2} \mathrm{D}_{3}$ is able to stimulate bone resorption in the presence of PTH (Reynolds, 1974 ; Garabedian ef al., 1974). However, the dietary intakes of vitamin $D_{3}$ were the same during the control and the low calcium periods and could not explain the slight decrease in plasma PTH level occurring during the low calcium diet.

In vitamin D-deficient pigs we have observed a positive correlation between PTH levels and the length of the deficiency (Pointillart, Garel and Guéguen, 1978a). Thus, the high vitamin $D$ intake in the present experiments may have inhibited PTH secretion. Fox ef al. (1977) suggest that the $1.25(\mathrm{OH})_{2} \mathrm{D}_{3}$ alone is responsible for intestinal adaptation in pigs fed a low calcium diet. Vitamin $D$ metabolites are known to be active in the treatment of hypocalcemia during parturient paresis (Gast et al., 1977 ; Barlet, 1976, 1977 ; Sachs et al., 1977). In previous work using a vitamin D-deficient diet or a high phosphorus diet, we have observed in both cases a decrease in plasma calcium concentration with no change in plasma PTH (Pointillart, Garel and Guéguen, $1978 a, b)$, but with marked shifts in plasma CT levels. Our experiments in pigs led to the conclusion that CT secretion is more sensitive than PTH secretion to changes in plasma calcium level. Care ef al. (1968) have already demonstrated in this species the fine responsiveness of the CT secretion rate to the blood calcium level.

The decrease in plasma calcium level is small as compared to the fall in dietary calcium intake, and this observation agrees with other results reported previously for pigs : low dietary calcium intakes (from 0.15 to 0.33 p. 100) given during 3 months did not change plasma calcium concentration (Horvath and Papp, 1972 ; Doige, Owen and Mills, 1975 ; Stockland and Blaylock, 1973).

Dietary calcium deficiency over a long period has no marked effect either on 
bone calcium content or on bone ash (p. 100 dry bone). A decrease of 7.6 p. 100 in bone calcium content was observed by Horvath and Papp (1972), whereas Stockland and Blaylock (1973) found a 3 p. 100 reduction, and no change occurred according to Doige, Owen and Mills (1975) and Pond, Walker and Kirtland (1978). In our experiments, the ash content ( 65 p. 100 of the dry weight) and calcium content ( 22.7 p. 100 of the dry weight) of metacarpal bone seemed normal. Severe deformations of the nasal septum were however observed as well as brachygnathism in one animal. The last findings, combined with elevated urinary hydroxyproline, strongly suggest the presence of a marked bone resorption. In fact, neither plasma calcium levels, nor bone calcium content or plasma PTH levels are indicative of a dietary calcium deficiency in pigs. This conclusion was confirmed in the recent work of Metel (1978) in which growing pigs, fed a low calcium diet $(0.3 \mathrm{p} .100)$ from 50 to $100 \mathrm{~kg}$, were not hypocalcemic as compared to controls receiving 0.75 p. 100 of calcium in the diet. The ash and calcium contents of bones from pigs fed the low calcium diet were not different from those of control pigs. It is also possible that calcium or ash contents (expressed in p. 100 of dry bone) of one or some bones does not reflect the general degree of demineralization of the skeleton. Differences may be found probably between bones in the responsiveness to a low calcium diet. Even if calcium deficiency did not apparently cause any change in the degree of bone mineralization, the bone mass may be decreased. However, the present data do not permit us to draw any definitive conclusion on this question.

In pigs we must also emphasize the importance of the relationships between the plasma concentrations of magnesium and CT already observed (Pointillart, Garel and Guéguen, 1978b). In the present experiments, during the control period and the last period of the low calcium diet, an inverse relationship was established between magnesemia and plasma CT levels.

The presence of an inverse relationship between plasma CT and PTH only during the first and third periods of low calcium diet indicated some disturbance in hormonal equilibrium during the second low calcium period (after tetany crisis). It also appeared that mechanisms involved in blood calcium regulation might change throughout the period of the low calcium diet since different correlations between CT and $\mathrm{Ca}$ and between CT and PTH occurred during the three intervals of the low calcium diet. A similar conclusion was drawn from results obtained on pigs fed a high phosphorus diet (Pointillart, Garel and Guéguen, 1978b).

In conclusion, the low calcium diet given to young growing pigs during 1.5 months induced a small decrease in calcemia and no change in plasma PTH levels; but plasma CT levels were greatly decreased. Our results and those from others obtained in pigs demonstrate an adaptation to unbalanced calcium-phosphorus diets. Although hormonal mechanisms are involved in the adaptation of the animals to the low calcium dief, other mechanisms (i. e. intestinal absorption) are the main factors of this response and PTH is probably marginal. The plasma magnesium level seems to play an important role in the CT-PTH hormonal equilibrium in pigs. 
Acknowledgements. - We thank Dr. Duhamel for help in statistical analysis. Urinary hydroxyproline was estimated through the courtesy of Mrs. Monique Allez. Figures were constructed by Miss Catherine Briand and the animals were cared for by Messrs. Gauthier and Guichaux. Purified bovine PTH was kindly supplied by Drs. J. A. Parsons and J. M. Zanelli. We are particularly grateful to Mr. J. Choay for providing us with Iniprol. This study was partly supported by the ATP No. 2417 of the CNRS.

Résumé. Quatre porcs en croissance, âgés de 12 semaines, ont reçu un régime témoin contenant 0,5 p. 100 de calcium puis, pendant 6 semaines, un régime carencé contenant 0,1 p. 100 de calcium $(\mathrm{BCa})$. Deux heures après le repas du matin ef sept heures après, les teneurs du plasma en calcium, magnésium, phosphore minéral, calcitonine (CT) ef parathormone (PTH) ont éfé mesurées durant la période témoin et durant la période $\mathrm{BCa}$.

Les échantillons ont été récoltés sur 4 périodes de 10 jours environ, une durant la période témoin et trois durant la période $\mathrm{BCa}(\mathrm{BCa} 1, \mathrm{BCa} 2, \mathrm{BCa} 3)$, les valeurs analysées portant sur 7 jours par période.

L'administration du régime carencé en calcium entraîne une baisse des teneurs plasmatiques en calcium et en calcitonine ef une hausse de l'hydroxyprolinurie. L'apparition de crises de tétanie (période $\mathrm{BCa} 2$ ) est suivie d'une baisse légère mais significative de la teneur en PTH du plasma. La magnésémie est plus élevée dans les périodes 2 et 3 du régime $\mathrm{BCa}$ que dans la période 1 et la période témoin.

L'absence d'élévation de la teneur en PTH du plasma, en relation avec la richesse du régime en vitamine $D$ et/ou en magnésium et les rôles respectifs de la $C T$ et de la PTH dans l'espèce porcine sont discutés. La baisse assez modérée de la calcémie (12 p. 100 maximum) sans réponse parathormonale est discutée en relation avec les réactions du porc aux déséquilibres phospho-calciques. Les troubles osseux constatés (cloison nasale, machoire) et l'augmentation de l'hydroxyprolinurie pourraient indiquer que les paramètres étudiés ( $\mathrm{Ca}$ et $\mathrm{PTH}$ ) ne permettent pas d'apprécier la gravité d'une carence calcique. II semble également se confirmer que dans cette espèce la $C T$ est plus sensible aux variations de la calcémie que la PTH.

Le rôle de la magnésémie dans l'équilibre endocrinien CT-PTH est également discuté.

\section{References}

BARLET J. P., 1971. Rôle de la calcitonine dans la régulation du métabolisme phosphocalcique des ruminants. Cas particulier : le syndrome vitulaire de la vache laitière. Thèse d'état Fac. Sci. ClermontFerrand, France.

BARLET J. P., 1976. Prophylaxie et thérapeutique de l'hypocalcémie vitulaire par les isomères ou les métabolites de la viłamine D. I. - Le 5-6 trans 25 hydroxycholécalciférol. Ann. Biol. anim. Bioch. Biophys., 16, 709-718.

BARLET J. P., 1977. Prophylaxie et thérapeutique de l'hypocalcémie vitulaire par les isomères ou les métabolites de la vitamine D. II. - Le $1 \propto$ hydroxycholécalciférol. Ann. Biol. anim. Bioch. Biophys., 17, 363-371.

BLUM J. W., FISCHER J. A., 1975. Die Bedeutung des Parathormones für die homeostatische Kontrolle der Serum-Kalziumkonzentration beim Rind. Schweiz. Landwirt. Mh., 53, 124-130.

BLUMIJ. W., FISCHER J. A., SCHWOEDER D., HUNZIKER W., BINSWANGER V., 1974. Acule parathyroid hormone response : sensitivity, relationship to hypocalcemia and rapidity. Endocrinology, 95, 753-759.

BLUM J. W., MAYER G. P., POTTS J. T. Jr., 1974. Parathyroid hormone responses during sponlaneous hypocalcemia and induced hypercalcemia in cows. Endocrinology. 95, 84-92.

BOREL J. P., CARANJOT J. M., JAYLE M. F., 1967. Les modes de fractionnement des peptides urinaires contenant de l'hydroxyproline. Clin. chim. Acta, 16, 409-416. 
CARE A. D., COOPER C. W., DUNCAN T., ORIMO H., 1968. Study of thyrocalcitonin secretion by direct measurement of in vivo secretion rates in pigs. Endocrinology, 83, 161-169.

CHEN P. S., TORIBARA T. Y., WARNER H., 1956. Microdetermination of phosphorus. Anal. Chem., 28, 1756-1758.

DOIGE C. E., OWEN B. D., MILLS J. H. L., 1975. Influence of calcium and phosphorus in growth and skeletal development of growing swine. Canad. J. Anim. Sci., 55, 147-164.

FOX J., SWAMINATHAN R., MURRAY T. M., CARE A. D., 1977. Role of the parathyroid glands in the enhancement of intestinal calcium absorption in response to a low calcium diet. J. Endocr., 74, 345-354.

GARABEDIAN M., TANAKA Y., HOLICK M. F., DE LUCA H. F., 1974. Response of intestinal calcium transport and bone calcium mobilization to 1,25 Dihydroxyvitamin $D_{3}$ in thyroparathyroidectomized rats. Endocrinology, 94, 1022-1027.

GAREL J. M., BARLET J. P., 1975. Plasma immunoreactive calcitonin and parathyroid hormone levels in parturient cows. J. Endocr., 66, 299-300.

GAREL J. M., BARLET J. P., 1976. A radioimmunoassay for bovine parathyroid hormone. J. Physiol. Paris, 72, 249-257.

GAREL J. M., CARE A. D., BARLET J. P., 1974. A radioimmunoassay for ovine calcitonin : an evaluation of calcitonin secretion during gestation, lactation and fœital life. J. Endocr., 62, 497509.

GAREL J. M., SAVAJOL H., BARLET J. P., 1976. Plasma immunoreactive calcitonin fevels in pregnant ewes and their lambs. Biol. Neonate, 28, 207-218.

GAST D. R., MARQUARDT J. P., JORGENSEN N. A., DE LUCA H. F., 1977. Efficacy and safety of $1 \alpha$ hydroxyvitamin $D_{3}$ for prevention of parturient paresis, J. Dairy Sci., 60, 1910-1920.

HORVATH Z., PAPP L., 1972. Studies of $\mathrm{Ca}$ and P metabolism in atrophic rhinitis of swine. I. Studies on the predisposing role of Ca depletion. Acta vet. Acad. Sci. Hung., 22, 37-43.

HUNTER W. M., GREENWOOD F. C., 1962. Preparation of 131/-labelled human growth hormone of high specific activity. Noture, Lond., 194, 495-496.

MASSRY S. G., COBURN J. W., KLEEMAN C. R., 1970. Evidence for suppression of parathyroid gland activity by hypermagnesemia. J. clin. Invest., 49, 1619-1629.

MAYER G. P., BLUM J. W., DEFTOS L. J., 1975. Diminished prepartal plasma calcitonin concentrations in cows developing parturient hypocalcemia. Endocrinology, 96, 1478-1485.

METEL M., 1978. Le métabolisme phospho-calcique chez le porc en croissance. Incidence d'une carence en calcium ou en phosphore. Mémoire de fin d'études ITPA - Société Sanders, Athis-Mons, France.

NUNEZ E. A., KROOK L., WHALEN J.P., 1976. Effect of calcium depletion and subsequent repletion on parathyroids, parafollicular (C) cells and bone in the growing pig. Cell Tiss. Res., 168, 373-384.

POND W. G., WALKER E. F. Jr., KIRTLAND D., 1978. Effect of dietary Ca and P levels from 40 to $100 \mathrm{~kg}$ body weight on body weight gain and bone and soft tissue mineral concentrations. J. Anim. Sci., 46, 686-691.

POINTILLART A., GAREL J. M., GUÉGUEN L., 1978a. Calcemia regulation in the vitamin D deficient growing pig. Ann. Biol. anim. Bioch. Biophys., 18, 167-174.

POINTILLART A., GAREL J. M., GUÉGUEN, 1978b. Plasma calcitonin and parathyroid hormone levels in growing pigs on different diets. 1. - High phosphorus diet. Ann. Biol. anim. Bioch. Biophys., 18, 699-709.

RADDE I. C., WITTERMANN E. R., PENSUWAN S., 1968. Effect of thyroid and parathyroid on hypocalcemia occuring after a magnesium load. Endocrinology, 83, 1255-1292.

RAMBERG C. F. Jr., MAYER G. P., KRONFELD D. S., POTTS J. T. Jr., 1976. Dietary calcium, calcium kinetics and plasma parathyroid hormone concentrations in cows. J. Nutr., 106, 671-679.

REYNOLDS J. J., 1974. The role of 1.25 Dihydroxycholecalciferol in bone metabolism Biochem. Soc., spec. publ. 3, 91-102.

SACHS M., BAR A., COHEN R., MAZUR Y., MAYER E., HURWITZ S., 1977. Use of $1 \alpha$-hydroxycholecalciferol in the prevention of bovine parturient paresis. Am. J. vet. Res., 38, 2039-2041.

SAEKI T., HAYASHI M., 1976. Acute Parathyroid response in EDTA-induced hypocalcemia and its application to a fonctional test of the parathyroid gland in cattle. Nat. Inst. Anim. Hith. Quat., 17, 67-72. 
SERAFINI-CESSI F., CESSI C., 1964. An improved method for the determination of hydroxyproline in protein hydrolysats. Analyt. Biochem., 8, 527-528.

SHERWOOD L. M., POTTS J. T. Jr., CARE A. D., MAYER G. P., AURBACH G. D., 1966. Evaluation by radioimmunoassay of factors controlling the secretion of parathyroid hormone : intravenous infusions of calcium and EDTA in the cow and goat. Nature, London, 209, 52-55.

STOCKLAND W. L., BLAYLOCK L. G., 1973. Influence of dietary calcium and phosphorus levels on the performance and bone characteristics of growing-finishing swine. J. Anim. Sci., 37, 906-912.

THOMASSET M., POINTILLART A., CUISINIER-GLEIZES P., GUÉGUEN L., 1979. Effect of vitamin D or calcium deficiency on duodenal, jejunal and ileal calcium-binding protein and on plasma calcium and 25 -hydroxycholecalciferol levels in the growing pig. Ann. Biol. anim. Bioch. Biophys., 19 (in press). 